\title{
Sağlıklı Bireylerde Depresyona Yatkınlık Durumunun Postüre Etkisinin İncelenmesi
}

DOI: 10.26466/opus.614496

\author{
Abdurrahim Yıldız* - Rüstem Mustafaoğlu** \\ * Uzm.Fzt., İstanbul Üniversitesi-Cerrahpaşa, Lisansüstü Eğitim Enstitüsü, Kardiyoloji Anabilim \\ Dalı, İstanbul/Türkiye \\ E-Posta: fzt.abdurrahim@yandex.com \\ ORCID: 0000-0002-6049-0705 \\ ** Dr. Öğr.Üyesi., İstanbul Üni.-Cerrahpaşa, Sağlık Bilimleri Fakültesi, Fizyoterapi ve \\ Rehabilitasyon Bölümü, Bakırköy/İstanbul/ Türkiye \\ E-Posta: ahiska_1944@hotmail.com \\ ORCID: 0000-0001-7030-0787
}

$\ddot{O} z$

Çalışmanın amacı, sağlıklı bireylerde depresyona yatkınlık durumunun postür bozukluğuna etkisini araştırmak ve cinsiyete göre farklılık gösterip göstermediğini incelemekti. Sağhlklı bireylerin depresyona yatkınlık durumları Beck Depresyon Ölçeği (BDÖ)'i kullanılarak değerlendirildi. Postür analizleri ise deneyimli fizyoterapist tarafindan önden (anterior), yandan (lateral) ve arkadan (posterior) olmak üzere üç yönden değerlendirildi. Çalışmaya katılmaya gönüllü 151 sağlıklı kişi BDÖ'den aldıkları puana göre 2 gruba ayrildı. BDÖ>10 olan katıllmcilar depresyona yatkın grup, Grup I (n=79); BDÖ<10 olan katılımcilar normal olan bireyler, Grup II ( $n=72)$ olarak ayrıldı. Grup I'deki bireylerde; Başın lateral fleksiyonu $(p=0,01)$, pes planus ( $p=0,03)$, başın anterior tilti $(p=0,04)$, omuz protraksiyonu $(p=0,02)$, kifotik duruş $(p=0,02)$, lomber lordoz artışı $(p=0,03)$ ve skapula alatanın $(p=0,02)$ Grup II'deki bireylere göre anlamlı derecede sık görüldü̈̆̈̈ saptandı. Grup I'de yer alan kadınlarda başın lateral fleksiyonu $(p=0,04)$, sağ omuz düşüklü̈̆̈̈ $(p=0,022)$, omuz protraksiyonu $(p=0,01)$, kifotik duruş $(p=0,003)$ ve skapula alata $(p=0,01)$ gibi postüral bozukluklar Grup II'de yer alan kadınlara göre istatistiksel olarak daha sık olduğu saptandi. Grup I'de yer alan erkeklerde ise sadece pes planus ( $p=0,04)$ Grup II'de yer alan erkeklere göre istatistiksel olarak daha sıktı. Çalışmamızda elde edilen bulgulara göre sağ lıklı bireylerde depresyona yatkınlık durumunun bireylerde başın anterior tilti, başın lateral fleksiyonu, omuz protraksiyonu, kifotik duruş, skapula alata ve pes planus gibi postüral bozuklukların daha sık görülmesine neden olmaktadır. Depresyona yatkınlık durumunun kadınlarda erkeklere göre daha fazla postüral sapmalara neden olduğ $u$ görüldü.

Anahtar Kelimeler: Depresyon, postür, spinal dizilim, postür analizi 


\title{
Investigation of the Effect of Depression Tendency Status on Posture in Healthy Individuals
}

\begin{abstract}
The aim of the study was to investigate the effect of depression tendency status on posture disorder and to see if it differs according to gender in healthy individuals. Depression tendency statuses of healthy individuals were evaluated by the Beck Depression Scale (BDS). Posture evaluation was performed by experienced physiotherapist from three directions: anterior (anterior), lateral (lateral) and posterior (posterior). A total of 151 healthy people who volunteered to participate in the study were divided into two groups according to the score they got from the BDS. Participants with BDS $>10$ refer depressed individuals, Group I $(n=79)$; participants with $B D S<10$ refer normal individuals, Group II $(n=72)$. In Group I individuals, anterior tilt of the head ( $p=0.04$ ), lateral flexion of the head ( $p=0.01$ ), shoulder protraction ( $p=0.02)$, scapula alata $(p=0.02)$, kyphotic posture $(p=0.02)$, increased lumbar lordosis $(p=0.03)$ and pes planus $(p=0.03)$ were found to be significantly more frequent than Group II individuals. Postural disorders such as; lateral flexion of the head $(p=0.04)$, right shoulder depression $(p=0.022)$, shoulder protraction $(p=0.01)$, kyphotic posture $(p=0.003)$ and scapula alata $(p=0.01)$ in women of Group I were found to be statistically more frequent than in women of Group II. In men of Group I, it was found that only pes planus $(p=0.04)$ was statistically more common than in men of Group II. According to the findings obtained in our study, depression tendency status in healthy individuals causes more common postural disorders such as anterior tilt of the head, lateral flexion of the head, shoulder protraction, kyphotic posture, scapula alata and pes planus. It was seen that the depression tendency status caused more postural deviations in women than men.
\end{abstract}

Keywords: depression, posture, spinal alignment, posture analysis 


\section{Giriş}

Depresyona yatkın olan kişilerde görülen fiziksel belirtiler arasında psikomotor aktivitelerde gecikme, yorgunluk, azalan enerji ve ağrı yer almaktadır. Depresyona yatkın kişilerin motor ve bilişsel işlevlerindeki değişiklikler günlük yaşamlarındaki değişimlere karşı uyum sağlamaların etkileyebilmektedir. Depresyona yatkın olan bireyler, normal bireylere göre yürürken daha yavaş yürüme, gevşek postür ve daha düşük stabiliteye sahip olma eğilimindedirler (Michalak, Troje, Fischer, Vollmar, Heidenreich ve Schulte, 2000; Lemke, Wendorff, Mieth, Buhl ve Linnemann, 2000). Literatürde bireylerin depresyona yatkınlık düzeyleri sıklıkla Beck ve ark. (1996) tarafından adolesan ve erişkinlerde depresyonun davranışsal bulgularını ölçmek amacıyla 1961 yılında geliştirilmiştir. 1978 yılında ölçeğin tümü revize edilerek şiddeti tanımlayan duplikasyonlar ayıklanmış ve hastaların bugünü de kapsayacak biçimde son bir haftalık durumlarını işaretlemeleri istenmiştir. Ölçek, Türkçe'ye Beck Depresyon Ölçeği adıyla çevrilmiş geçerlik ve güvenirlik çalışması yapılmıştır (Hisli, 1988).

Postür, aktif ve inaktif olmak üzere iki şekilde incelenmektedir. İnaktif postür, dinlenmek veya uyumak için alınan vücut pozisyonudur. Aktif postür ise, dik duruş ve aktiviteler sırasında oluşan vücut pozisyonlarını kapsamaktadır. Aktif postürü devam ettirebilmek birçok kasın birbiriyle entegre olarak çalışmasını gerektirmektedir (Otman, Demirel ve Sade, 1995). Doğru postür veya dik duruş önemli bir sağlık belirtecidir (McEvoy ve Grimmer, 2005; Wallden, 2009). Bazı postüral sapmalar kas fonksiyonunu olumsuz etkilemektedir. Bireyleri ağrı ve patolojik kas-iskelet sistemi bozukluklarına yatkın hale getirebilmekte ve sağliklı olmayan vücut dizilimini tetikleyebilmektedir (James, Castaneda, Miller ve Findley, 2009; Do Rosario, 2014).

Postürü etkileyen intrinsik ve ekstrinsik faktörlerin; kalıtım, sosyo-ekonomik seviye ve duygusal faktörler olduğu belirtilmektedir (Penha, João, Casarotto, Amino ve Penteado, 2005). Duygusal değişiklikler, duygusal durumla uyumlu kas değişikliklerine neden olabilir. Duruş postürü güvenilir duygusal bir bilgi kaynağıdır ve duygunun vücutta nasıl ifade edildiğini göstermektedir (Coulson, 2004). Bu bağlamda postür, duygusal sorunların tanı ve tedavisinde önemli bir yardımcı araç olabilir (Canales, Cordás, Fiquer, Cavalcante ve Moreno, 2010). Literatür incelendiğinde, depresyon ile postür arasındaki ilişkiyi inceleyen çalışmaların kısıtlı sayıda olduğu görülmektedir (Canales, 
Fiquer, Campos, Soeiro-de-Souza ve Moreno, 2017; Prins, Crous ve Louw, 2008). Yürüme hızında azalma ve gevşek postürün, üzgün ve depresyona yatkın olan bireylerin yürüme paternini ifade ettiği bildirilmiştir (Michalak, Troje, Fischer, Vollmar, Heidenreich ve Schulte, 2000). Bir diğer çalışmada, depresyon skorları ile skolyoz açısı, baş ve omuz eğimi ve omuz protraksiyonu arasında doğrusal bir ilişki olduğu görülmüsstür (Do Rosario, Diógenes, Mattei ve Leite, 2013). Moslehi ve ark., (Moslehi, Saiiari ve Marashiyan, 2011) çalışmalarında, kifoz açısı ile depresif belirtiler arasında pozitif bir ilişki olduğunu rapor etmiştir. Servikal bölge ile omuz arasındaki açıda 10-30 derecelik bir değişimin ağrıyı arttırdığı, ağrının da kişinin ruhsal durumunu olumsuz etkilediği bildirilmiştir (McEvoy ve Grimmer, 2005). Tüm bu bilgilere rağmen, henüz depresif bireylerde postüral değişikliklerin altında yatan nörofizyolojik mekanizmalar hakkında çok az şey bilinmektedir. Majör depresyon tanısı almış bireylerde psikomotor performanstaki değişikliklerin olası mekanizması olarak dorsal striatum da dahil olmak üzere bazal ganglionların dopamin bakımından zengin bölgelerinde işlev bozukluğuna neden olabileceği düşünülmektedir (Ebert, Loew, Feistel ve Pirner, 1996; Martinot, Bragulat ve Artiges, 2001).

Çalışmamızın amacı, depresyona yatkınlık durumunun postür bozukluğuna etkisini araştırmak ve cinsiyete göre farklılık gösterip göstermediğini incelemekti.

\section{Yöntem}

\section{Çalışma Grubu}

Çalışmamız kesitsel tipte bir araştırma olup, evrenini Mart 2018-Haziran 2019 tarihleri arasında Auralife Sağlıklı Yaşam Merkezi'ne başvuran 18 yaş ve üzeri sağlıklı, çalışmaya katılmaya gönüllü 151 genç oluşturmuştur. Çalışmaya dahil edilme kriterleri; $18-25$ yaş arası olmak, kas-iskelet sistemi hastalığının olmaması, vücudunun herhangi bir yerinde ağrı olmaması ve vücut kütle indeksinin $<30 \mathrm{~kg} / \mathrm{m}^{2}$ 'nin altında olması olarak belirlenmiş olup dışlama kriterleri ise; psikiyatrik tanı almış olmak, son üç ayda psikolojik veya psikiyatrik destek almış olmak, mental veya fiziksel bir sağlık sorununa sahip olmak ve verilen anketleri eksik doldurmuş olmak şeklinde belirlendi. 
Katılımcılara anket doldurulmadan önce araştırmanın amacı açılandı. Çalışmanın gönüllülük esasına dayalı olduğu söylendi ve katılımcılardan bilgilendirilmiş gönüllü olur formu ile yazılı izinleri alındı. Çalışma gerekli izinler alındıktan sonra, Helsinki Deklerasyonu'na uygun olarak yürütüldü. Çalışmaya dahil edilme kriterlerine uyan 179 sağlıklı gönüllü değerlendirildi. On sekiz katılımcının değerlendirme verileri eksik olduğundan ve 10 katılımcıda skolyoz tespit edildiğinden toplam 28 katılımcı çalışma dışı bırakılarak; çalışma toplam 151 katılımc ile tamamlandı. Katılımcılar Beck Depresyon Ölçeği'nden aldıkları puana göre 2 gruba ayrıldı; Beck Depresyon Ölçeği puanı $>10$ olanlar, Grup I ( $n=79)$; Beck Depresyon Ölçeği puanı $<10$ olanlar, Grup II ( $n=72)$ olarak sinıflandırıldı. Beck Depresyon Ölçeği'nden 10 ve üzeri puan alanlar depresif (depresyona yatkın ya da depresyon açısından riskli) bireyler olarak, 9 ve altı puan alan bireyler ise normal bireyler olarak kabul edildi.

\section{Verilerin Toplanması}

Demografik bilgiler: Çalışmaya katılan sağlıklı bireylerin yaş, cinsiyet, boy ve kilo gibi demografik bilgileri sorgulanarak kaydedildi.

Depresyona yatkınlık düzeyi: Sağlıklı bireylerin depresyon duygu durumuna yatkınlık düzeyleri Beck Depresyon Ölçeği ile değerlendirildi. Bu ölçek, katılımclarda depresyon yönünden riski belirlemek ve depresif belirtilerin düzeyini ve şiddet değişimini ölçmektedir (Köroğlu, 2012). Cevaplayıc1 21 depresyona yatkınlık belirtisini 0 ila 3 arasında değişen 4'lü bir ölçek üzerinden değerlendirmektedir. Dolayısıyla toplam puanlar 0 ile 63 arasında değişmekte ve yüksek puan depresyon şiddetinin fazlalığına ya da depresyon riskinin düzeyine işaret etmektedir (Beck, Steer ve Brown, 1996). Testte 0-9 puan normal düzey, 10-16 puan hafif depresyon ya da depresyon açısından hafif derecede riskli, 17-29 puan orta depresyon ya da depresyon açısından orta derecede riskli ve 30-63 puan şiddetli depresyon ya da depresyon açısından yüksek riskli olarak değerlendirilebilr. Testin Türk dilinde geçerlilik ve güvenilirlik çalışması, Hisli tarafından yapılmıştır (Hisli, 1988).

Postür Analizi: Postür analizinin amacı, hastada mevcut postüral deviasyonların saptanarak buna uygun tedavi programlarının verilebilmesi; ayrıca ola- 
bilecek değişikliklerin değerlendirilmesidir. Çalışmada, postür analizine hastanın çıplak ayakla ve uygun giysilerle kendini rahat hissettiği pozisyonda durmasıyla başlandı. Katılımcılar önden (anterior), yandan (lateral) ve arkadan (posterior) olmak üzere üç yönden deneyimli fizyoterapist tarafından değerlendirildi (Kendall, McCreary, Provance, Rodgers ve Romani, 2005). Analizde, çekül, mezura, deri bölgelerini işaretlemek için özel kalemler kullanıldı. Postür analizi yapılırken herhangi bir postüral bozukluk veya sapma olup olmadığına bakılarak not edildi (Otman, Demirel ve Sade, 1995).

\section{Verilerin Analizi}

Verilerin istatiksel analizi SPSS 20.0 paket programı kullanılarak yapıldı. Çalışmada değerlendirmeye alınan değişkenler, ortalama (Ort), standart sapma (SS), frekans (n) ve yüzde (\%) değerleri ile tanımlandı. Frekans, görülen bozukların kişiler arasındaki dağılımını hesaplamak için kullanıldı. Yüzdeler, görülen bozuklukların kişiler arasındaki yüzdelik dağılımını görmek için kullanıldı. Bütün verilerin hesaplamasında parametrik testler kullanıldı. Çalışmayı oluşturan grupların demografik ve klinik özelliklerinin karşılaştırılmasında nicel/sayısal veriler için bağımsız gruplarda t-testi ve nitel/sayısal olmayan veriler için ise Ki-kare testi kullanıldı. Gruplar arası verilerin karşılaştırması bağımsız gruplarda t-testi ve Ki-kare testi ile yapıldı. İstatistiksel anlamlılık için $\mathrm{p}<0,05$ değeri kullanıldı.

\section{Bulgular}

Çalışmaya katılan gönüllülerin demografik bilgileri Tablo-1'de verildi. Grup I ve Grup II'deki katılımcıların yaş ortalamalarının sırasıyla 21,9ะ1,7 yıl ve $21,4 \pm 1,8$ yil olduğu görüldü. Demografik veriler açısından gruplar arasında istatistiksel olarak anlamlı bir fark saptanmadı $(p>0,05)$ (Tablo-1). Katılımc1ların cinsiyete göre dağılımları Şekil-1'de gösterildi. Cinsiyet dağılımları açısından gruplar arasında istatistiksel olarak anlamlı bir fark görülmedi $(\mathrm{p}=0,675)$. 


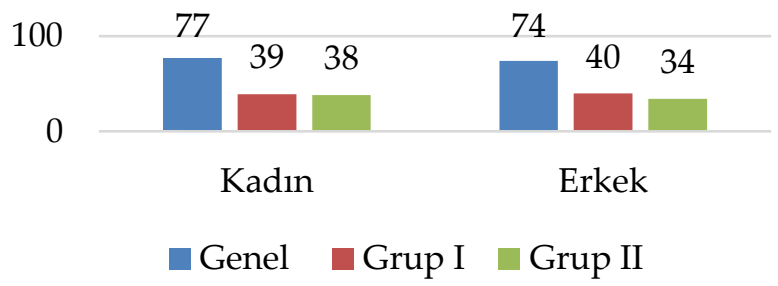

Şekil-1.Katılımcıların cinsiyete göre dă̆ılımları

Tüm katılımcıların Beck Depresyon Ölçeği'nden aldıkları puanlara göre dağılımları Şekil-2' de verildi. Beck Depresyon Ölçeği'ne göre 0-9 puan arasında puan alanlar ( $\mathrm{n}=72$ ) normal olan kişiler olup Grup II'yi oluşturmaktadır. Ölçekten 10-63 arası puan alan kişiler de depresif kişiler $(n=79)$ olarak Grup I'i oluşturmaktadır. Grup I'i oluşturan bireylerin hafif depresif ( $n=36)$, orta depresif ( $n=34)$ ve şiddetli depresif $(n=9)$ şeklinde dağılım gösterdiği saptandı.

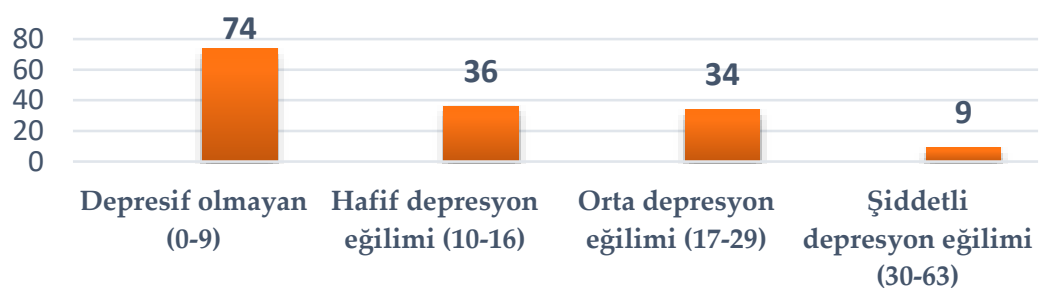

Şekil-2. Tüm katılımcıların Beck Depresyon Ölçeği puanlarına göre dağıllmmları

Katılımcılarda görülen postüral bozukların dağılımı Tablo-2'de verildi. Katılımclar arasında en sık görülen üç postüral bozukluğun sırasıyla; başın anterior tilti $(\% 48,9)$, omuz protraksiyonu $(\% 37,8)$ ve sağ omuz düşüklüğü (\%30,5) olduğu görüldü.

Tablo-1. Katılımcıların demografik verileri

\begin{tabular}{|c|c|c|c|c|}
\hline & $\begin{array}{l}\text { Genel(n=151) } \\
\text { Ort } \pm S S\end{array}$ & $\begin{array}{l}\text { Grup I(n=79) } \\
\text { Ort } \pm S S\end{array}$ & $\begin{array}{l}\text { Grup II(n=72) } \\
\text { Ort } \pm S S\end{array}$ & ${ }^{*}$ p-değeri \\
\hline Yaş (yıl) & $21,7 \pm 1,8$ & $21,9 \pm 1,7$ & $21,4 \pm 1,8$ & 0,354 \\
\hline Boy $(\mathrm{cm})$ & $170,2 \pm 8,7$ & $170,9 \pm 9,4$ & $169,5 \pm 7,8$ & 0,351 \\
\hline Kilo (kg) & $64,3 \pm 11,9$ & $65,5 \pm 12,8$ & $63,0 \pm 10,7$ & 0,182 \\
\hline VKİ (kg/m2) & $22,1 \pm 2,7$ & $22,2 \pm 27$ & $21,8 \pm 2,8$ & 0,346 \\
\hline BDÖ & $12,0 \pm 9,1$ & $19,7 \pm 7,2$ & $4,9 \pm 2,6$ & 0,001 \\
\hline
\end{tabular}

Grup I: normal bireyler; Grup II: depresyona yatkın bireyler; BDÖ: Beck Depresyon Ölçeği; VKİ: Vücut Kitle Indeksi; Ort: ortalama; SS: Standart Sapma; cm: santimetre; kg: kilogram; m:metre

*Bă̆ımsız gruplarda $t$-test $i$ 
Saptanan postüral bozuklukların cinsiyete göre dağılımları Tablo-3'te verildi. Erkeklerde en sık görülen postüral bozukluk başın anterior tilti $(\mathrm{n}=44)$ iken, kadınlarda ise omuz protraksiyonu $(n=36)$ idi. Cinsiyete göre karşılaştırma yapıldığında kadınlarda, omuz protraksiyonu $(p=0,003)$ ve skapula alata $(\mathrm{p}=0,002)$ sik görülen postüral bozukluklar iken erkeklerde ise pes planusun $(\mathrm{p}=0,014)$ en sık görülen postüral bozukluk olduğu saptandı (Tablo-3).

Postüral bozukluk sıklığının depresyona yatkınlık varlığı durumuna göre genel ve cinsiyete göre gruplar arası karşılaştırması Tablo-4'te verildi. Genel olarak Grup I'de başın lateral fleksiyonu $(\mathrm{p}=0,015)$, pes planus $(\mathrm{p}=0,037)$, başın anterior tilti ( $\mathrm{p}=0,041)$, omuz protraksiyonu $(\mathrm{p}=0,027)$, kifotik duruş $(\mathrm{p}=0,028)$, lomber lordozda artıs $(\mathrm{p}=0,039)$ ve skapula alata $(\mathrm{p}=0,024)$ Grup II'ye göre istatistiksel olarak anlamlı derecede sık olduğu saptandı. Grup I kadınlarda başın lateral fleksiyonu $(\mathrm{p}=0,040)$, sağ omuz düşüklüğü $(\mathrm{p}=0,022)$, omuz protraksiyonu $(\mathrm{p}=0,018)$, kifotik duruş $(\mathrm{p}=0,003)$ ve skapula alata $(p=0,013)$ gibi postüral bozuklukların Grup II'ye göre istatistiksel olarak anlamlı derecede daha sık görüldüğü saptandı. Grup I'de yer alan erkek katılımclarda ise sadece pes planus $(\mathrm{p}=0,046)$ Grup II'de yer alan erkek katılımcılara göre istatistiksel olarak daha sık idi.

Tablo-2. Tüm katılanlarda görülen postüral bozukların dağılımı

\begin{tabular}{lccc}
\hline \multicolumn{1}{c}{ Postüral Bozukluklar } & $\begin{array}{c}\text { Postüral bozukluk } \\
\text { Yok (n) }\end{array}$ & $\begin{array}{c}\text { Postüral bozukluk } \\
\text { Var (n) }\end{array}$ & $\begin{array}{c}\text { Görülme sıklı̆̆1 } \\
\text { (\%) }\end{array}$ \\
\hline Başın lateral fleksiyonu & 137 & 14 & 9,3 \\
Omuz düşüklüğü-Sağ & 105 & 46 & 30,5 \\
Omuz düşüklüğü-Sol & 124 & 27 & 17,9 \\
Pelvisin lateral tilti & 137 & 14 & 9,3 \\
Ayakta valgus & 138 & 13 & 8,7 \\
Ayakta varus & 148 & 3 & 2,0 \\
Pes planus & 117 & 34 & 22,6 \\
Başın anterior tilti & 78 & 73 & 48,9 \\
Omuz retraksiyonu & 146 & 5 & 3,4 \\
Omuz protraksiyonu & 94 & 57 & 37,8 \\
Kifotik duruş & 113 & 38 & 25,2 \\
Lomber lordozda düzleşme & 137 & 14 & 9,3 \\
Lomber lordozda artma & 116 & 35 & 24,2 \\
Skapula seviye eşitsizliği & 144 & 7 & 4,7 \\
Skapula alata & 140 & 11 & 7,3 \\
Servikal lordozda düzleşme & 150 & 1 & 0,7 \\
Taşıma açısında artma & 148 & 3 & 2,0 \\
\hline
\end{tabular}

n: frekans; \%: yüzde 
Depresif olan kadınlarda başın lateral fleksiyonu $(\mathrm{p}=0,040)$, sağ omuz düşüklüğü $(p=0,022)$, omuz protraksiyonu $(p=0,018)$, kifotik duruş $(p=0,003)$ ve skapula alata $(\mathrm{p}=0,013)$ gibi postüral bozuklukların Grup I'de Grup II'ye göre istatistiksel olarak anlamlı derecede daha sık görüldüğü saptandı. Grup 1'de yer alan erkek katılımclarda ise sadece pes planus $(p=0,046)$ Grup II'de yer alan erkek katılımclara göre istatistiksel olarak daha sık idi.

\section{Tartışma}

Çalışma sonuçlarına göre depresyona yatkınlık durumu dikkate alınmadan değerlendirildiğinde çalışmaya katılan tüm sağlıklı bireylerde başın anterior tilti, omuz protraksiyonu ve sağ omuz düşüklügünün en sık görülen postüral bozukluklar olduğu saptandı. Cinsiyete göre karşılaştırma yapıldığında ise pes planus erkeklerde, omuz protraksiyonu ve skapula alata kadınlarda en sık görülen postüral bozukluktu. Depresyona yatkınlık durumu dikkate alındığında ise depresif olan katılımcılarda başın lateral fleksiyonu, pes planus, başın anterior tilti, omuz protraksiyonu, kifotik duruş, lomber lordozda artış ve skapula alatanın normal olan bireylere göre daha sık görüldügü saptandı. Depresyona yatkın olan kadınlarda başın lateral fleksiyonu, sağ omuz düşüklüğü, omuz protraksiyonu, kifotik duruş ve skapula alata gibi postüral bozukluklar normal olan kadınlara göre daha sıktı. Depresyona yatkın olan erkeklerde ise sadece pes planusun normal olan erkeklere göre daha sık görüldüğ̈̈ saptandı.

Tablo-3. Tüm katılımcılarda cinsiyete göre postüral bozuklukların görülme sıklı̆̆ı ve karşılaştırması

\begin{tabular}{lccccc} 
& \multicolumn{2}{c}{ Erkek (n=74) } & \multicolumn{2}{c}{ Kadın (n=77) } & * p-değeri \\
& Var (n) & Yok (n) & Var (n) & Yok (n) & \\
\hline Başın lateral fleksiyonu & 9 & 65 & 5 & 72 & 0,078 \\
Omuz düşüklügü-Sağ & 25 & 49 & 21 & 56 & 0,488 \\
Omuz düşüklügü-Sol & 15 & 59 & 12 & 65 & 0,146 \\
Pelvisin lateral tilti & 6 & 68 & 8 & 69 & 0,629 \\
Ayakta valgus & 8 & 64 & 5 & 72 & 0,724 \\
Ayakta varus & 3 & 71 & 0 & 77 & 0,074 \\
Pes planus & 23 & 51 & 11 & 66 & $\mathbf{0 , 0 1 4}$ \\
Başın anterior tilti & 44 & 40 & 33 & 44 & 0,090 \\
Omuz retraksiyonu & 2 & 72 & 3 & 74 & 0,186 \\
Omuz protraksiyonu & 21 & 53 & 36 & 41 & $\mathbf{0 , 0 0 3}$ \\
Kifotik duruş & 15 & 59 & 23 & 54 & 0,083 \\
Lomber lordozda düzleşme & 9 & 65 & 5 & 72 & 0,149 \\
Lomber lordozda artma & 14 & 60 & 21 & 56 & 0,076
\end{tabular}




\begin{tabular}{llllll} 
Skapula seviye eşitsizliği & 3 & 71 & 4 & 73 & 0,503 \\
Skapula alata & 2 & 72 & 9 & 68 & $\mathbf{0 , 0 0 2}$ \\
Servikal lordozda düzleşme & 0 & 74 & 1 & 76 & 0,325 \\
Taşıma açısında artma & 3 & 71 & 0 & 77 & 0,292 \\
\hline n: frekans & & & &
\end{tabular}

Literatür incelendiğinde, tıp fakültesi ve sağlık yüksekokulu öğrencilerinde depresyona yatkınlı belirtilerinin yaygınlığının araştıııldı̆̆ı bir çalışmada, tıp fakültesi öğrencilerinin Beck Depresyon Ölçeği puan ortala-

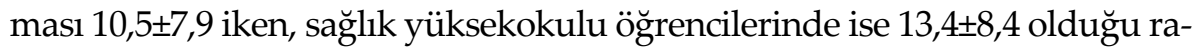
por edilmiştir (Kaya, Genç, Kaya ve Pehlivan, 2007). Üniversite öğrencilerinde depresif belirtilerin araştırıldığı bir diğer çalışmada, Beck Depresyon

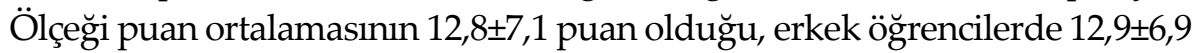
depresyon puanı, kı öğrencilerde 12,9 \pm 7,5 puan olduğu bildirilmiştir (Özdel, Bostancı, Özdel ve Oğuzhanoğlu, 2002). Çalışmamızda da benzer olarak Beck

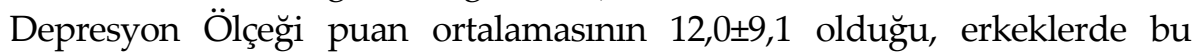

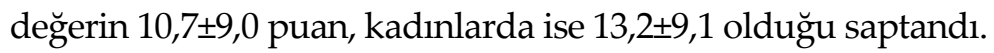

Canales ve ark. (2017) çalışmalarında, majör depresif bozukluğu olan kişilerin, depresif dönemlerde artmış baş fleksiyonu, artmış torasik kifoz, sol pelvik retroversiyon ve sol skapulanın abduksiyon yönünde bir eğilim gösterdiğini bulduklarını bildirmişlerdir. Yazarlar gözlenen bu baş duruşunun (başı ön eğme/aşağı bakma) anteriora çekme kuvvetlerinin ve posteriorda kompresyon kuvvetlerinin artmasına neden olabileceğini ileri sürmüşlerdir. Bu durumun bireyin duygusal durumunun, yüz kaslarının kasılmasına ve vücut duruşuna yansıdığını gösteren kanıtlarla uyumlu olduğunu bildirmişlerdir (Coulson, 2004; Ekman, 1993; Grammer, Fink, Oberzaucher, Atzmüller, Blantar ve Mitteroecker, 2004). Majör depresyonu olan hastalarda postür analizi ve beden imaj1, başın anterior tilti ve torasik kifoza eğilim "depresif bir duruş" olarak nitelendirilen interskapular mesafede artışı göstermektedir. Her ne kadar biz çalışmamızda sağlıklı bireylerin depresyona yatkınlık durumlarını değerlendirmiş olsak da, depresyona yatkın bireylerde yapılan bu çalışmaya benzer olarak başın anterior tilti, omuz protraksiyonu ve kifotik duruş gibi postüral bozuklukların yanı sıra başın lateral fleksiyonu, pes planus, lomber lordozda artma ve skapula alata gibi bozuklukların olduğu saptandı. 
Rosario ve ark. (2014) mevcut depresyon durumunun başın ve omuzların eğilmesi ile ilişkili olduğunu belirtmişlerdir. Her zamanki depresyon ve olağan üzüntü durumunun, omuz protraksiyonu ve omuz düşüklüğü ile ilişkili olduğunu bildirmişlerdir. Yolandi ve ark. (2009) da çalışmalarında benzer olarak, depresyonun omuz protraksiyonuna güçlü ve olumsuz etkisinin olduğu ve depresyon seviyesinin yüksekliğiyle dik duruşun ilişkili olduğunu bildirmişlerdir. Rosario ve ark. (2013) diğer bir çalışmalarında olağan üzüntü durumu ile omuzların protraksiyonu arasında açık bir ilişki olduğunu görmenin-mümkün olduğunu belirtmiştir. Canales ve ark. (2017), depresif olan bireyler ile depresif olmayan bireyleri karşılaştırdığı çalışmalarında baş postürü (aşağı), skapular postür ve torasik kifoz bakımından depresif grupta istatistiksel olarak anlamlı fark olduğunu bulduklarını bildirmişlerdir. Ayrıca, yazarlar depresyon ciddiyetinin torasik kifoz derecesini etkilediğini belirtmişlerdir. Çalışmamızda da benzer olarak depresif bireylerde başın lateral fleksiyonu, başın anterior tilti, omuz protraksiyonu, skapula alata ve kifotik duruşun depresif olmayanlara göre daha sık görüldüğü saptandı. Yukarıdaki çalışmalardan farklı ve üstün yönü olarak çalışmamızda hem depresif olan hem de normal olan bireylerde cinsiyete göre postür bozukluklarının karşılaştırılması yapılmıştır. Cinsiyete göre yapılan karşılaştırma sonuçlarımıza bakıldığında, depresyona yatkın grupta yer alan kadınlarda başın lateral fleksiyonu, sağ omuz düşüklüğü, omuz protraksiyonu, kifotik duruş ve skapula alata gibi postüral bozuklukların, depresyona yatkın grupta yer alan erkeklerde ise sadece pes planus görülmesi durumuna dayanarak depresyona yatkınlı duygu durumunun kadın postürü üzerinde daha fazla sapmalara neden olduğunu söyleyebiliriz.

Literatürde aşırı kifoz varlığının zayıf benlik kaygısı, üzüntü ve depresif belirtilerle ilişkili olduğu rapor edilmiştir (2014). Bu nedenle, tekrarlayan depresif atakların hem olumsuz duygusal durumlar hem de motor fonksiyon bozukluğu ile ilişkili postüral değişikliklere zemin hazırladığı düşünülmektedir. Çalışmamızda da depresif bireylerde kifotik duruş ve lomber lordozda artma durumunun normal bireylere göre daha sık olduğu saptandı.

\section{Sonuç}

Çalışmamız sonuçlarına göre depresyona yatkın olan katılımcılarda başın lateral fleksiyonu, pes planus, başın anterior tilti, omuz protraksiyonu, kifotik duruş, lomber lordozda artış ve skapula alata normal olan bireylere göre 
daha sık görülmekte. Ayrıca, depresyona yatkın olan kadınlarda başın lateral fleksiyonu, sağ omuz düşüklüğü, omuz protraksiyonu, kifotik duruş ve skapula alata gibi postüral bozukluklar normal olan kadınlara göre daha sık olduğu saptand1. Ek olarak, depresyona yatkın olan erkeklerde ise sadece pes planusun normal olan erkeklere göre daha sık görülmüştür. Bulgularımızı doğrulamak ve postüral yanlış dizilimin motor ve postüral kontroldeki değişikliklerden kaynaklanıp kaynaklanmadığını araştırmak için ileri çalışmalara ihtiyaç vardır.

Tablo-4. Postüral bozukluk sıklı̆̆ının depresyona yatkınlı durumuna göre genel ve cinsiyete göre gruplar arası karşılaştırması

\begin{tabular}{|c|c|c|c|c|c|c|c|c|c|}
\hline & \multicolumn{2}{|c|}{ Genel $(n=151)$} & \multicolumn{4}{|c|}{ Erkek $(n=74)$} & \multicolumn{3}{|c|}{ Kadın (n=77) } \\
\hline & $\begin{array}{c}\text { Grup } \\
\text { I }\end{array}$ & $\begin{array}{c}\text { Grup } \\
\text { II }\end{array}$ & $\begin{array}{c}{ }^{*} \mathrm{p}- \\
\text { değeri }\end{array}$ & $\begin{array}{c}\text { Grup } \\
\text { I }\end{array}$ & $\begin{array}{c}\text { Grup } \\
\text { II }\end{array}$ & $\begin{array}{c}{ }^{*} \text { p- } \\
\text { değeri }\end{array}$ & $\begin{array}{c}\text { Grup } \\
\text { I }\end{array}$ & $\begin{array}{c}\text { Grup } \\
\text { II }\end{array}$ & $\begin{array}{c}{ }^{*} \mathrm{p}- \\
\text { değeri }\end{array}$ \\
\hline Başın lateral fleksiyonu & 11 & 3 & 0,015 & 7 & 2 & 0,115 & 4 & 1 & 0,040 \\
\hline $\begin{array}{l}\text { Omuz } \\
\text { düşüklüğü-Sağ }\end{array}$ & 26 & 20 & 0,207 & 11 & 14 & 0,416 & 15 & 6 & 0,022 \\
\hline $\begin{array}{l}\text { Omuz } \\
\text { düşüklüğgü-Sol }\end{array}$ & 15 & 12 & 0,834 & 9 & 6 & 0,247 & 6 & 6 & 1,000 \\
\hline Pelvisin lateral tilti & 6 & 8 & 0,704 & 3 & 3 & 1,000 & 3 & 5 & 0,456 \\
\hline Ayakta valgus & 8 & 5 & 0,121 & 5 & 3 & 0,456 & 3 & 2 & 0,635 \\
\hline Ayakta varus & 0 & 3 & 0,095 & 0 & 3 & 0,077 & 0 & 0 & na \\
\hline Pes planus & 23 & 11 & 0,037 & 15 & 8 & 0,046 & 8 & 3 & 0,105 \\
\hline Başın anterior tilti & 44 & 33 & 0,041 & 24 & 20 & 0,641 & 20 & 13 & 0,063 \\
\hline Omuz retraksiyonu & 3 & 2 & 0,803 & 1 & 1 & 1,000 & 2 & 1 & 0,276 \\
\hline $\begin{array}{l}\text { Omuz } \\
\text { protraksiyonu }\end{array}$ & 36 & 21 & 0,027 & 12 & 9 & 0,446 & 24 & 12 & 0,018 \\
\hline Kifotik duruş & 24 & 14 & 0,028 & 7 & 8 & 0,775 & 17 & 6 & 0,003 \\
\hline $\begin{array}{l}\text { Lomber lordozda } \\
\text { düzleşme }\end{array}$ & 8 & 6 & 0,644 & 4 & 5 & 0,486 & 4 & 1 & 0,166 \\
\hline Lomber lordozda artma & 22 & 13 & 0,039 & 10 & 4 & 0,077 & 12 & 9 & 0,315 \\
\hline $\begin{array}{l}\text { Skapula seviye } \\
\text { eşitsizliği }\end{array}$ & 3 & 4 & 0,554 & 2 & 1 & 0,277 & 1 & 3 & 0,221 \\
\hline Skapula alata & 9 & 2 & 0,024 & 1 & 1 & 1,000 & 8 & 1 & 0,013 \\
\hline $\begin{array}{l}\text { Servikal lordozda } \\
\text { düzleşme }\end{array}$ & 1 & 0 & 0,293 & 0 & 0 & na & 1 & 0 & 0,314 \\
\hline $\begin{array}{l}\text { Taşıma } \\
\text { açısında artma }\end{array}$ & 2 & 1 & 0,765 & 2 & 1 & 0,556 & 0 & 0 & na \\
\hline
\end{tabular}

Grup I: depresyona yatkın bireyler; Grup II: normal bireyler; na: istatistiksel hesaplama yapılamadı

*Ki-kare testi 


\title{
EXTENDED ABSTRACT
}

\section{Investigation of the Effect of Depression Tendency Status on Posture in Healthy Individuals}

\author{
Abdurrahim Yıldız - Rüstem Mustafaoğlu \\ Health Science University- Istanbul University-Cerrahpaşa
}

Physical symptoms seen in people prone to depression include delay in psychomotor activities, fatigue, decreased energy and pain. Individuals who are prone to depression tend to have slower walking, loose posture and lower stability when walking than normal individuals(Michalak, Troje, Fischer, Vollmar, Heidenreich ve Schulte, 2000; Lemke, Wendorff, Mieth, Buhl and Linnemann, 2000).

Maintaining an active posture requires many muscles to work integratedly(Otman, Demirel and Sade, 1995). Correct posture or upright posture is an important health marker (McEvoy and Grimmer, 2005; Wallden, 2009). Some postural deviations negatively affect muscle function. It can make individuals susceptible to pain and pathological musculoskeletal disorders and trigger unhealthy body alignment(James, Castaneda, Miller and Findley, 2009; Do Rosario, 2014).

It is stated that there are heredity, socio-economic level and emotional factors affecting the posture (Penha, João, Casarotto, Amino and Penteado, 2005). Emotional changes can cause muscle changes that are compatible with the emotional state. Posture is a reliable emotional source of information and shows how emotion is expressed in the body (Coulson, 2004).

The aim of the study was to investigate the effect of depression tendency status on posture disorder and to see if it differs according to gender in healthy individuals.

This is a cross-sectional study and 151 healthy young people aged 18 and over who applied to the Auralife Healthy Center between March 2018 and June 2019 were volunteers to participate in the study. Before the questionnaire was filled in, the purpose of the research was explained. The study was carried out in accordance with the Helsinki Declaration. A total of 151 healthy people who volunteered to participate in the study were divided into two groups according to the score they got from the Beck Depression Scale(BDS). 
Participants with BDS $>10$ refer depressed individuals, Group I $(n=79)$; participants with BDS $<10$ refer normal individuals, Group II $(n=72)$.

Demographic data: Demographic information such as age, gender, height and weight of healthy individuals who participated in the study were questioned and recorded.

The depression tendency status: Depression levels of healthy individuals were evaluated using the Beck Depression Scale. In the scale, it can be evaluated as 0-9 points normal level, 10-16 points mild depression or slightly risky in depression, 17-29 points moderate depression or moderately risky in depression, and 30-63 points in severe depression or high risk for depression(Beck, Steer and Brown, 1996).

Posture Analysis: Participants were evaluated by experienced physiotherapists: anterior, lateral and posterior aspects(Kendall, McCreary, Provance, Rodgers and Romani, 2005). While performing posture analysis, it was noted by looking for any postural disorders or deviations(Otman, Demirel ve Sade, 1995).

At the end of the research, the data were analyzed using SPSS 20.0 package program. The variables evaluated in the study were defined by mean (Mean), standard deviation (SD), frequency (n) and percentage (\%). Parametric tests were used to analize all data. İndependent $t$-test was used for quantitative/numerical data and Chi-square test for qualitative/non-numerical data in comparison of demographic and clinical characteristics of the groups. $\mathrm{P}<0.05$ was used for statistical significance.

Demographic data of the volunteers participating in the study is shown in Table-1. The average age of the participants in Group I and Group II was 21.9 \pm 1.7 years and $21.4 \pm 1.8$ years, respectively. There was no statistically significant difference between the groups in terms of demographic data ( $p>0.05)$.

The distribution of postural disorders seen in the participants is given in Table-2. The three most common postural disorders among the participants are; anterior tilt of the head (48.9\%), shoulder protraction(37.8\%) and right shoulder depression(30.5\%).

Distribution of postural disorders detected by gender are pesented in Table-3. The most common postural disorder in men was the anterior tilt of the head $(n=44)$, while in women, it was shoulder protraction $(n=36)$. When comparing by gender, shoulder protraction $(\mathrm{p}=0.003)$ and scapula alata 
$(\mathrm{p}=0.002)$ were common postural disorders in women, while pes planus $(p=0.014)$ was the most common postural disorder in men.

In general Group I, lateral flexion of the head $(\mathrm{p}=0.015)$, pes planus $(\mathrm{p}=0.037)$, anterior tilt of the head $(\mathrm{p}=0.041)$, shoulder protraction $(\mathrm{p}=0.027)$, kyphotic posture $(\mathrm{p}=0.028)$, increase in lumbar lordosis $(\mathrm{p}=0.039)$ and scapula alata ( $p=0.024$ ) were found to be statistically significant compared to Group II. In Group I women, postural disorders such as lateral flexion of the head $(\mathrm{p}=0.040)$, right shoulder depression $(\mathrm{p}=0.022)$, shoulder protraction $(p=0.018)$, kyphotic posture $(p=0.003)$ and scapular alata $(p=0.013)$ was observed statistically significantly more frequent than in Group II women. In male participants in Group I, only pes planus $(\mathrm{p}=0.046)$ was statistically more frequent than in Group II male (Table 4).

According to the results of our study, it was found that the anterior tilt of the head, shoulder protraction and right shoulder depression were the most common postural disorder in all healthy individuals participating in the study. When compared by gender, pes planus was seen as the most common postural disorder in men, shoulder protraction and scapula alata in women.Considering the depression tendency status, the participants in the depression prone group, the lateral flexion of the head, pes planus, anterior tilt of the head, shoulder protraction, kyphotic posture, increase in lumbar lordosis, and scapulae alata were more frequent than normal individuals. It was found that women who are prone to depression has more common postural disorders such as lateral flexion of the head, right shoulder depression, shoulder protraction, kyphotic posture, and scapula alata than that women with normal. It was found that only pes planus was seen more frequently in men who were in a group prone to depression than men who were normal. Further studies are needed to confirm our findings and to investigate whether postural misalignment is due to changes in motor and postural control.

Similarly to our finding, Canales et al. (2017) reported that people who has a major depressive disorder, during depressive episodes they have a increased head flexion, increased thoracic kyphosis, left pelvic retroversion, and left scapula abduction tendency. In another study, Rosario et al. (2014), stated that the current depression state is related to the bending of the head and shoulders. They reported that the usual depression and usual sadness were associated with shoulder protraction and shoulder depression. Yolandi et al. (2009), also reported that depression had a strong and negative effect on shoulder 
protraction and that the high level of depression was related to the upright posture. Canales et al. (2017) reported that they found a statistically significant difference in the depressive group in terms of head posture (down), scapular posture and thoracic kyphosis in their studies comparing with nondepressed individuals.

In the current study participants who has depression tendency, the lateral flexion of the head, pes planus, anterior tilt of the head, shoulder protraction, kyphotic posture, increase in lumbar lordosis, and scapulae alata were more frequent than normal individuals. However,it was found that women who are prone to depression has more common postural disorders such as lateral flexion of the head, right shoulder depression, shoulder protraction, kyphotic posture, and scapula alata than that women with normal. In addition, it was found that only pes planus was seen more frequently in men who were in a group prone to depression than men who were normal. Further studies are needed to confirm our findings and to investigate whether postural misalignment is due to changes in motor and postural control.

\section{Kaynakça / References}

Beck A.T. (1961). An inventory for measuring depression. Arch Gen Psychiatry, $4(6), 561-71$.

Beck, A.T., Steer, R.A., ve Brown, G.K. (1996). Beck depression inventory. II. San Antonio Psychological Corporation. 78(2), 490-498.

Brink, Y., Crous, L.C., Louw, Q.A., Grimmer-Somers, K., ve Schreve, K. (2009). The association between postural alignment and psychosocial factors to upper quadrant pain in high school students: A prospective study. Manual therapy, 14(6),647-653.

Canales, J.Z., Cordás, T.A., Fiquer, J.T., Cavalcante, A.F., ve Moreno, R.A. (2010). Posture and body image in individuals with major depressive disorder: A controlled study. Brazilian Journal of Psychiatry, 32(4), 375-380.

Canales, J.Z., Fiquer, J.T., Campos, R.N., Soeiro-de-Souza, M.G.,ve Moreno, R.A. (2017). Investigation of associations between recurrence of major depressive disorder and spinal posture alignment: A quantitative cross-sectional study. Gait \& posture, 52, 258-264.

Coulson M. (2004). Attributing emotion to static body postures: Recognition accuracy, confusions, and viewpoint dependence. Journal of nonverbal behavior, 28(2), 117-139. 
Do Rosário, J.L.P. (2014). Photographic analysis of human posture: a literature review. Journal of bodywork and movement therapies, 18(1), 56-61.

Do Rosário J.L.P., Diógenes, M.S.B., Mattei, R., Leite, J.R. (2013). Can sadness alter posture? Journal of bodywork and movement therapies, 17(3), 328-331.

Ebert, D., Loew, T., Feistel, H., ve Pirner, A. (1996). Dopamine and depression-striatal dopamine D 2 receptor SPECT before and after antidepressant therapy. Psychopharmacology, 126(1), 91-94.

Ekman P. (1993). Facial expression and emotion. American psychologist, 48(4), 384.

Grammer, K., Fink, B., Oberzaucher, E., Atzmüller, M., Blantar, I., ve Mitteroecker, P. (2004). The representation of self-reported affect in body posture and body posture simulation. Collegium antropologicum. 28(2), 159-173.

Hisli, N. (1988). Beck Depresyon Envanterinin gecerliliği üzerine bir çalışma (A study on the validity of Beck Depression Inventory.). Psikoloji Dergisi, 6, 118-122.

James, H., Castaneda, L., Miller, M.E., ve Findley, T. (2009). Rolfing structural integration treatment of cervical spine dysfunction. Journal of Bodywork and Movement Therapies, 13(3), 229-238.

Kaya, M., Genç, M., Kaya, B., ve Pehlivan, E. (2007). Tıp fakültesi ve sağlık yüksekokulu öğrencilerinde depresif belir yaygınlığı, stresle başa çıkma tarzları ve etkileyen faktörler. Türk Psikiyatri Dergisi, 18(2), 137-146.

Kendall, F.P., McCreary, E., Provance, P., Rodgers, M., ve Romani, W. (2005). Muscles: Testing and function, with posture and pain (Kendall, Muscles). Philadelphia: Lippincott Williams \& Wilkins.

Köroğlu E. (2012). Psikiyatride kullanılan klinik ölçekler. Ankara: HYB yayınları. Lemke, M.R., Wendorff, T., Mieth, B., Buhl, K., ve Linnemann, M. (2000). Spatiotemporal gait patterns during over ground locomotion in major depression compared with healthy controls. Journal of psychiatric research, 34(4-5), 277-283.

Martinot, M-L.P., Bragulat, V., Artiges, E., et al. (2001). Decreased presynaptic dopamine function in the left caudate of depressed patients with affective flattening and psychomotor retardation. American Journal of Psychiatry, 158(2), 314-316.

McEvoy, M.P., ve Grimmer, K. (2005). Reliability of upright posture measurements in primary school children. BMC musculoskeletal disorders, 6(1), 35. 
Michalak, J., Troje, N.F., Fischer, J., Vollmar, P., Heidenreich, T., ve Schulte, D. (2009). Embodiment of sadness and depression-gait patterns associated with dysphoric mood. Psychosomatic medicine, 71(5), 580-587.

Moslehi, M., Saiiari, A., ve Marashiyan, F. (2011). Study of the relationship between Kyphosis, anxiety, depression and aggression of high school boy students. Procedia-Social and Behavioral Sciences, 15, 1798-1801.

Otman, A., Demirel, H., ve Sade, A. (1995). Tedavi hareketlerin de temel değerlendirme prensipleri. 16. Ankara: Hacettepe Üniversitesi Fizik Tedavi ve Rehabilitasyon Yuksekokulu Yayınları.14-20.

Özdel, L., Bostanc1, M., Özdel, O., ve Oğuzhanoğlu, N.K. (2002). Üniversite öğrencilerinde depresif belirtiler ve sosyodemografik özelliklerle ilişkisi. Anadolu Psikiyatri Dergisi, 3(3), 155-161.

Penha, P.J., João ,S.M.A., Casarotto, R.A., Amino, C.J., ve Penteado, D.C. (2005). Postural assessment of girls between 7 and 10 years of age. Clinics. 60(1), 9-16.

Ramezanzade, H., ve Arabnarmi, B. (2011). Relationship of self-esteem with forward head posture and round shoulder. Procedia-Social and Behavioral Sciences, 15, 3698-3702.

Rosario, J.L., Diógenes, M.S.B., Mattei, R., ve Leite, J.R. (2014). Differences and similarities in postural alterations caused by sadness and depression. Journal of bodywork and movement therapies, 18(4), 540-544.

Wallden, M. (2009). The neutral spine principle. Journal of bodywork and movement therapies, 13(4), 350-361.

\section{Kaynakça Bilgisi / Citation Information}

Yıldız, A. ve Mustafaoğlu, R. (2020). Sağlıklı bireylerde depresyona yatkınlık durumunun postüre etkisinin incelenmesi. OPUSUluslararası Toplum Araştırmaları Dergisi, 15(24), 2746-2763. DOI: 10.26466/opus658882 